\title{
THE MORPHO-FUNCTIONAL PARAMETERS OF RAT PITUITARY HORMONE PRODUCING CELLS AFTER GENISTEIN TREATMENT
}

\author{
Svetlana Trifunović, Verica Milošević \\ Department of Cytology, Institute for Biological Research "Siniša Stankovic'”, \\ University of Belgrade, Bul Despot Stefan 142, 11060 Belgrade, Serbia
}

Received 2 June 2017; Received in revised form 17 July 2017; Accepted 30 August 2017

\begin{abstract}
Phytoestrogens are a diverse group of steroid-like compounds that occur naturally in many plants. There are various types of phytoestrogens, including the best-researched isoflavones which are commonly found in soy. The consumption of soy products has many health benefits, including protection against breast cancer, prostate cancer, menopausal symptoms, heart disease and osteoporosis. In contrast, use of hormonally active compounds-isoflavones may unfortunately interfere with the endocrine system and can have far-reaching consequences. Genistein, the most abundant soy-bean derived isoflavone, possesses a ring system similar to estrogens and acts through an estrogen receptor (ER)-mediated mechanism, by increasing or decreasing the transcription of ER-dependent target genes. Also, genistein can act on cells through ER non-dependent mechanisms, such as tyrosine kinase inhibitor. The neuroendocrine systems are responsible for the control of homeostatic processes in the body, including reproduction, growth, metabolism and energy balance, and stress responsiveness. It is well known, that estrogen is important for development of the neuroendocrine system in both sexes. At the pituitary level, estrogen is known to affect the regulation of all hormone producing (HP) cells, by direct and/or indirect mechanisms. Due to structural and functional resemblance to estrogen, the question may arise of whether and how genistein affects the morphofunctional features of pituitary HP cells. This review deals with the consequences of genistein's effects on morphological, stereological and hormonal features of HP cells within the anterior pituitary gland. Transparency on this issue is needed because isoflavones are presently highly consumed. Inter alia, genistein as well as other isoflavones, are present in various dietary supplements and generally promoted as an accepted alternative to estrogen replacement therapy. Potential isoflavone biomedical exploitation is not only limited to estrogen replacement therapy, so it should be treated in a wider context of different ageing symptoms remediation.
\end{abstract}

Key words: genistein, pituitary gland, hormone producing cells

\section{INTRODUCTION}

Phytoestrogens are considered to be plant-based compounds that elicit similar effects to estrogen, due to their structural and/or functional similarity. One major class of phytoestrogens are the lignans, which are components of plant cell walls. Other groups of phytoestrogens are phenolic compounds, of which the isoflavones and coumestans are the most

Corresponding author: Dr. Svetlana Trifunović, PhD

E-mail address: lanat@ibiss.bg.ac.rs

Present address: Department of Cytology, Institute for Biological Research "Siniša Stanković" 142, Despot Stefan, Blvd., 11060 Belgrade, Serbia Phone: +381-11-2078320 Fax: +381-11-2761433

Copyright: (C) 2017 Trifunović S. This is an open-access article published under the terms of the Creative Commons Attribution License which permits unrestricted use, distribution, and reproduction in any medium, provided the original author and source are credited. Competing Interests: The authors have declared that no competing interests exist.

Available Online First: 19 November 2017

Published on: 15 March 2018

https://doi.org/10.1515/macvetrev-2017-0027 researched groups (1). Even though phytoestrogens are abundant in huge number of plants, soybeans and soy based foods are the greatest source of isoflavones in human and animal diets. In diets, most of isoflavones are in a glycoside form that is biologically less active (genistin, daidzin) and these molecules are cleaved by intestinal bacteria to the aglycone forms (genistein, daidzein), which are then biologically active (2).

Genistein (G; Fig.1.) is one of the best characterized isoflavones. It was first isolated from soybeans in 1931 (3), while its estrogenic activity wasn't identified until the $1950 \mathrm{~s}(4,5)$.

Thus, it was found that $G$ increased uterus weight in several animal species (5). G possesses two phenolic rings ( $\mathrm{B}$ ring is linked to the heterocyclic ring at the $\mathrm{C} 3$ ) similar to estrogens, so it can act through an estrogen receptor (ER)mediated mechanism, by increasing or decreasing 
<smiles>O=c1c(-c2ccc(O)cc2)coc2cc(O)cc(O)c12</smiles>

Figure 1. The chemical structure of genistein

the transcription of ER-dependent target genes (estrogenic, anti-estrogenic activity). It is able to bind to both type of ER (ER $\alpha$ and $\operatorname{ER} \beta$ ), however a higher potency toward ER $\beta$ is observed (6-8). Also, there is a difference in $\mathrm{G}$ bounding affinity for ER between in vivo and in vitro conditions. In vivo study showed the equal bounding affinity of isoflavones to $\mathrm{ER} \alpha$ and $\mathrm{ER} \beta$, while in vitro exhibited a higher binding affinity for $\operatorname{ER} \beta$ (9). The effect of $\mathrm{G}$ is dose dependent, and whether they will act as estrogen agonists or as antagonists depend on the quantity of isoflavones (10). Precisely, isoflavones are associated with the ERs who are available (at a low level of endogenous estrogen), and the estrogen effect is potentiated with an injection of lower doses of isoflavones (11). Furthermore, it is important to emphasize that the estrogenic potency of $\mathrm{G}$ is much weaker than that of physiological steroids, actually only $\sim 1 / 10,000$ to $1 / 50,000$ than that of estradiol (12). Genistein is a potent inhibitor of tyrosine protein kinases (PTKs), too $(13,14)$. Considering that PTKs inter alia catalyze phosphorylation of growth factors involved in tumor cell proliferation, genistein can potentially slow tumerogenesis. Inhibiting DNA topoisomerases, it can affect DNA replication $(15,16)$. Also, there is the ability of soy isoflavones to regulate androgen biosynthesis in Leydig cells due in part to action on Leydig cell $3 \beta-$ hydroxysteroid dehydrogenase activity (17). Plus, isoflavones indirectly exert their antioxidant effect by activating enzymes antioxidant protection: catalase, superoxide dismutase and glutathione peroxidase (18). Genistein is able to bind to androgen receptor (AR), as well. However, its ARbinding affinity is significantly lower as compared with testosterone and estradiol (19).

\section{Benefits and/or weaknesses of isoflavones use}

Isoflavones are recommended to have cancerprotective properties. Consequently, women whose diet is isoflavone-rich have a reduced risk and rates of breast cancer $(20,21)$. Also, the significant inverse association between breast cancer risk and urinary excretion of the isoflavone metabolite equol were observed (22). Shimizu et al. (23) study indicates the rate of breast cancer in immigrants from Japan after years of living in North America, as well as their daughters is almost the same as in the indigenous Americans, which highlights the importance of diet in the etiology of cancers. Besides the genistein-provoked inhibition of breast cancer cells proliferation, a similar effect was identified in prostate and colon cancer (24). Studies carried out on people of Japanese origin living in Hawaii, pointed the reduced risk of prostate cancer as a result of a diet rich in soy products (25).

Numerous data support the hypothesis that genistein has an impact on reducing the risk of cardiovascular disease, as a cardio-protective compound (26). The reduced level of lipids (30\%-40\% lower level of low-density lipoproteinLDL) provoked by isoflavones, is at least in part responsible for the cardio-protective effect (27). As we have mentioned above, $G$ is a powerful antioxidant too, and it is able to inhibit the oxidation of LDL, in vitro. Previous data showed that isoflavones prevent the formation of plaques in blood vessels of patients with atherosclerosis and inhibit the adhesion of cells, and in this way act as an antiatherogenic factor (28). The results of our research group indicated lower cholesterol levels and increased level of triglycerides in male rats after treatment with genistein and daidzein, which can reduce enthusiasm for their application (29).

Some studies suggest a possible role of soy isoflavones in bone metabolism and osteoporosis prevention (30, 31). Namely, in postmenopausal women who have consumed the soy enriched food the increase in bone mineral content has been observed. (32). Also, by reducing the level of alkaline phosphatase in the serum, genistein exerts its osteoprotective effect (33).

Similarly, we should not ignore the beneficial effect of isoflavones on menopause symptoms, such as heat waves ("hot flushes"), loss of vaginal secretions, poor sleep and anxiety accompanied by increased secretion of stress hormones (34). Our research has detected a lower level of stress hormone in old rats treated with $G$, which increases the interest in genistein application in andropause (35). Also, soy isoflavone prevented the development of adenocarcinomas in the prostate and seminal vesicles in a rat carcinogenesis model. Plus, the soy diet reduced the growth of transplantable 
prostate adenocarcinomas and inhibited tumor cell proliferation and angiogenesis of transplantable prostate cancer (36).

The estrogenic action of $\mathrm{G}$ has been examined and confirmed in two major estrogen responsive organs, the uterus and the ovaries $(37,38)$. More precisely, neonatal exposure to genistein caused a dramatic increase in ER $\alpha$ in granulosa cells in mice (37). The results from our study showed that ovaries exposed to genistein and daidzein have had healthier primordial and primary follicles and less atretic follicles, which means they increased the ovarian follicular reserve by stepping down transition from primordial to primary follicles and less atretic follicles in middle-aged rats (39). Also, we observed that genistein and daidzein exposure have decreased superoxide dismutase and catalase, indicating that soy phytoestrogens acted as free radical scavengers, which highlight their antioxidant potential (39). Increased serum progesterone level was observed following genistein and daidzein treatment, as well (39).

In addition to the mentioned benefits of isoflavones use, it has been understood for a long time that consumption of hormonally active plant constituents can adversely affect reproduction in domestic animals, up to induction of permanent infertility (40). Considering that estrogen can stimulate breast cancer cells, there are concerns that isoflavones may not be safe for women who have or already had breast cancer. While isoflavones in general should have an anti-estrogenic effect by blocking real estrogen, some studies in animals have found evidence that, under certain circumstances, soy isoflavones might stimulate breast cancer cells (41, 42). Also, Unfer at al. (43) showed that longterm treatment with soy phytoestrogens increased the occurrence of endometrial hyperplasia, which calls into question the long-term safety of phytoestrogens with regard to the endometrium. Human pre-natal exposure to isoflavones may affect human semen quality produce or contribute to male infertility, cause birth defects in male infants, breast and testicular cancers, obesity and other adverse health effects (44). Goldin et al., (45) presented that isoflavones might slightly decrease testosterone levels in man, as well. Further concerns relate to soy's potential effects on the thyroid gland. Thus, in patients with impaired thyroid function soy products have been observed to reduce absorption of thyroid medication (46). Also, in people who are iodine deficient isoflavones may directly inhibit the function of the thyroid gland (47). Soy isoflavones's consummation had no effect on thyroid hormone levels or actually increased levels in humans and animals, which make things more confusing (48). Considering that isoflavones are able to derail the normal endocrine signaling, they are classified into the category of an endocrine disruptor (49).

\section{Pituitary hormone-producing cells}

The central neuroendocrine systems are responsible for the control of homeostatic processes, including reproduction, growth, metabolism and energy balance, as well as stress responsiveness. The pituitary gland, as part of the neuroendocrine system, is often dubbed the "master gland" because its hormones control other parts of the endocrine system, namely the thyroid gland, adrenal glands, ovaries, and testes (50).

Anatomically, the pituitary is divided into adenohypohysis and neurohypophysis. The adenohypohysis is represented by the anterior lobe, the intermediary lobe and the infundibulotuberal lobe in mammals. Rat anterior pituitary lobe contains five types of hormone-producing (HP) cells: somatotrops (growth hormone - GH cells), lactotrophs (prolactin - PRL cells), corticotrops (adrenocorticotropin hormone - ACTH cells), thyrotrophs (thyroid stimulating hormone - TSH cells) and gonadotrophs (follicle-stimulating hormone - FSH and luteinizing hormone - LH cells, 51). Pituitary hormone synthesis and secretion represent the integrated processes, controlled by hypothalamic, intrapituitary and peripheral signals. Thus, GH secretion from pituitary somatotrophs is controlled by the interplay of growth hormone releasing hormone (GHRH) and somatostatin (SS), secreted from the hypothalamus (52). Prolactin, the pituitary hormone whose principal control is inhibitory, is regulated by dopamine (causing inhibition of prolactin secretion) and TRH (stimulated prolactin secretion) (51). The corticotrophinreleasing hormone $(\mathrm{CRH})$ and arginin-vasopresin from hypothalamus stimulate the release of ACTH from the pituitary, which in turn acts on the adrenal cortex to trigger the release of glucocorticoids (53). Thyreotropin releasing hormone (TRH) from the hypothalamus stimulates TSH cells to secrete TSH, which in turn stimulates the thyroid gland to produce thyroxin. The hypothalamus through the secretion of gonadotrophin-releasing hormone $(\mathrm{GnRH})$ governs the activity of the pituitary gland, an organ which serves as an amplifier, transmitting the brain signal via the secretion of LH and FSH, to act on the gonads (54).

Morphology of rat HP cells: GH cells are ovoid, sphericalor polyhedral cells with an 
eccentric nucleus and abundant, densely granulated cytoplasm. PRL cells are large, ovoid angular cells with an eccentric nucleus, more numerous in the female animals. ACTH cells are angular cells, sending cytoplasmic processes among neighboring cells, while nucleus follows the shape of the cell body. TSH cells are angular cells, too. Gonadotrophs are immunoreactive for both FSH and LH or only for one of these hormones. In females half of these cells are bihormonal, while in males almost all cells contain both hormones (55-59).

Dada et al. (56) analyzed cell types in pars distalis of the normal young rat with respect to their percentages and the relative volumes they occupy. In rats the percentages of cell types were: PRL approximately $50 \%$, GH $20 \%$, LH 5\%, FSH 4\%, ACTH $3 \%$ and TSH $2 \%$. However, this proportion is not represented in all studies dealing with percentage of hormone producing cells, due to different methods used for analyses, different sex, age, and species. The proportion of HP cells type changes dynamically, as a response to different endocrine demands $(60,61)$. Previously, it was thought that a particular type of HP cells synthesizes only one hormone and according to this principle cells are characterized as somatotrops, lactotrophs, etc. However, when the secretory granules of a certain HP cells revealed several hormones, the concept of the plurihormonalni HP cells was accepted. It was shown that $30 \%$ of all adenohypophysis HP cells in rats, mice and monkeys express mRNA for a variety of hormones (62). For example, subpopulation of gonadotropes and lactotropes also express GH (63).

Does genistein affect morphofunctional parameters of pituitary hormone-producing cells?

Most of pituitary HP cells are targeted by estrogens, through directand/or indirectmechanisms.
The direct action of estrogen is enabled due to the expression of ER in almost all type of pituitary cells (64). Thus, Yin et al. (65) and Milosevic et al. (66) observed that estradiol provoked: PRL cell proliferation by direct action and LH secretion by positive feedback action (indirect action) in female rats. Results from our study indicated the decreased relative intensity of fluorescence and smaller volume of middle-age female rat FSH and LH cells, while PRL cells were more numerous, following estradiol treatment $(0.625 \mathrm{mg} / \mathrm{kg}$ b.w.; 39). Also, stereological analysis has shown higher values of total number of rat ACTH cells, which was accompanied with the higher ACTH level, indicating the elevated synthesis and secretion of rat ACTH after estradiol treatment (67). On the other hand, the volume density of rat GH cells was reduced; total number of cells was unchanged, while the relative intensity of fluorescence of $\mathrm{GH}$ cells and $\mathrm{GH}$ blood level increased after estradiol treatment $(0.625 \mathrm{mg} / \mathrm{kg}$ b.w.; 68). Previous work from our laboratory indicated inhibition of TSH cells in middle-aged female rats after chronic application of estradiol $(0.625 \mathrm{mg} / \mathrm{kg}$ b.w; 69). From the all above it can be unambiguously concluded that estrogen impacts, directly or/and indirectly not only the function of HP cells, but also their stereological characteristics.

Due to structural and functional resemblance to the estrogen, the question may raise of whether and how $\mathrm{G}$ affects the morpho-functional features of pituitary HP cells. Considering that cell counts (stereology approach) have been essential in the discovery of important concepts in a variety of cell biology investigation, these findings are irreplaceable for the complete explanation of the impact of genistein on pituitary HP cells (70).

Using a stereological system (newCAST) Trifunovic et al. (68) showed the increase of
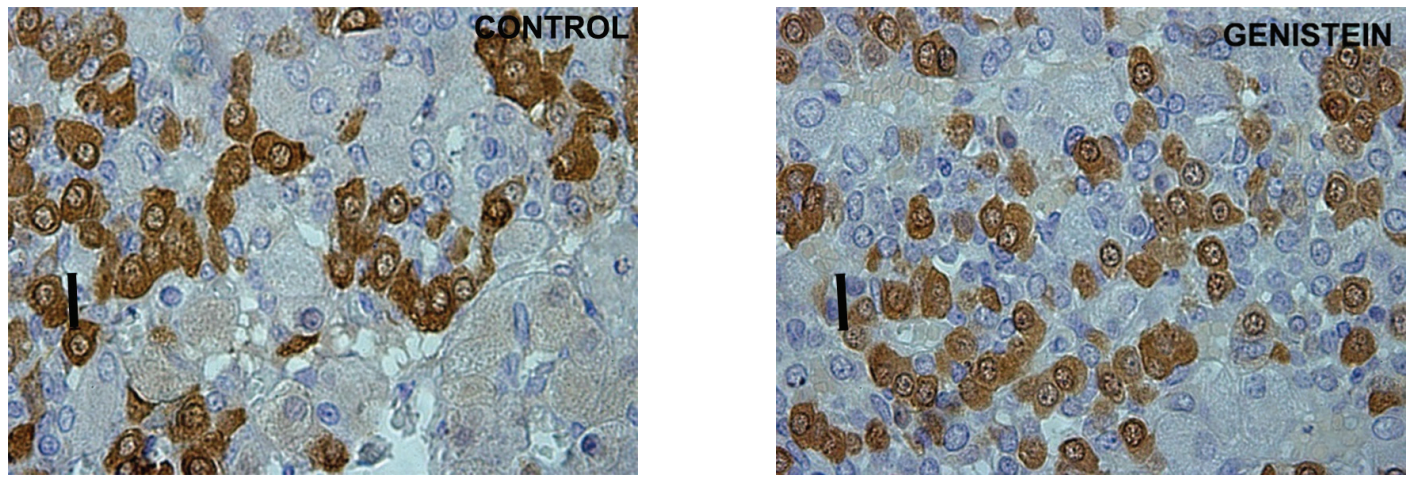

Figure 2. Immunoreactive somatotropes in the pituitary gland in control and genistein treated adult male rats. Scale bar $16 \mu \mathrm{m}$ 
A

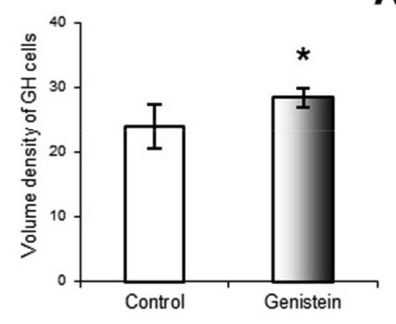

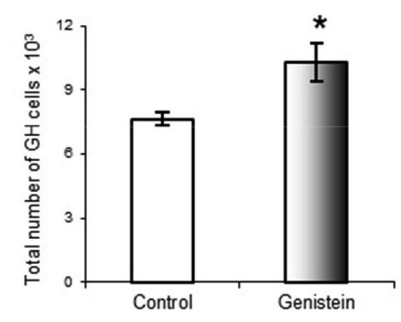

B

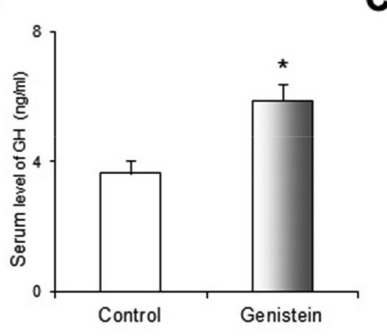

Figure 3. Volume density of somatotropes (GH cells; A); Total number of GH cells (B); Blood GH concentration (C) in control and genistein treated adult male rats. The values are means \pm standard deviation, $\mathrm{n}=6$ animals per group; * $\mathrm{p}<0.05$ vs. control

pituitary volume following chronic $G$ treatment (30 $\mathrm{mg} / \mathrm{kg}$ b.w.) in adult orchidectomized rats. Orchidectomized adult animals were used experimentally to minimize steroids influence and separate the effect of sex steroid and genistein. The same study has indicated the greater volume density and total number of pituitary GH cells, as well as GH blood level following $\mathrm{G}$ treatment. The increases of stereological parameters of GH cells are a result of $\mathrm{G}$ indirect action via $\mathrm{GHRH}$ and direct via ER, expressed in GH cells (71; Fig. 2 and Fig. 3).

More precisely, genistein action led to a higher volume density of GHRH in the Arc nucleus (72), probably operating through ER-dependent mechanisms, considering that $70 \%$ of those neurones express ER (73). If we compare the action of estradiol and genistein on morphfunctional parameters of GH cells, we can conclude that both treatments follow a similar course, the increase of $\mathrm{GH}$ cells action.

The similar conclusion, that genistein was an effective stimulator of GH secretion, was reached in the study on ewes (74). In orchidectomized middle-aged rats (animal model of andropause) genistein application provoked the increases of absolute and relative pituitary weight, which is explicable by their presumable estrogenic effect on the pituitary prolactin cells (75). Weaker immunohistochemical staining and immuno-fluorescent signal have been observed within GH cells in middle-age rats following $\mathrm{G}$ treatment, which is a different effect compared to adult rats (Fig. 4 and Fig. 5).

The Romanowicz et al. (76) data demonstrated that genistein may effectively modulate $\mathrm{LH}$ and PRL secretion in ovariectomized ewes, too. The data obtained in our experimental study indicated that genistein didn't change relative intensity of the fluorescent signal, while alterations in cell morphology were observed in gonadotropic and lactotropic cells in middle aged female rats (Fig. 6). In fact, gonadotropic and lactotropic pituitary cells were changed in shape, with unevenly stained cytoplasms which gave cells the appearance of vacuolization (39).
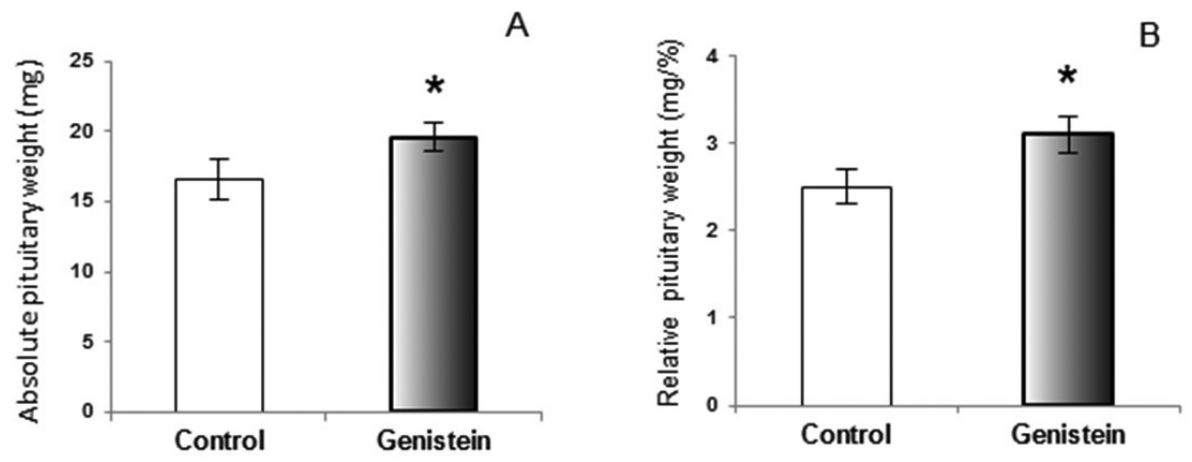

Figure 4. Absolute pituitary weight (A); Relative pituitary weight (B) in control and genistein treated andropausal rats. The values are means \pm standard deviation, $n=6$ animals per group; ${ }^{*} p<0.05$ vs. control 

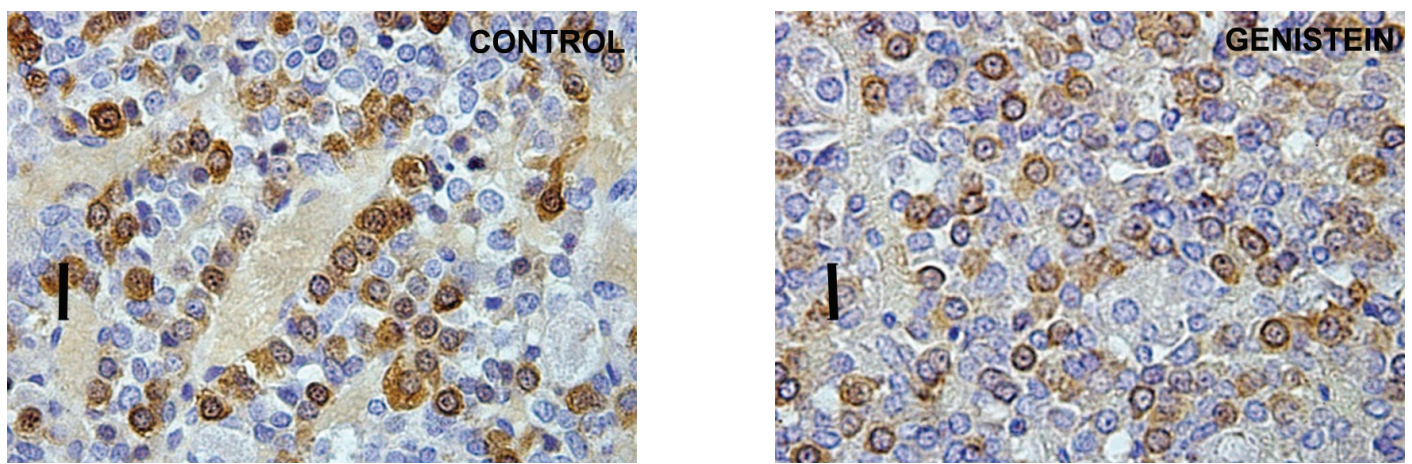

Figure 5. Immunoreactive somatotropes in the pituitary gland in control and genistein treated middle-aged rats. Scale bar $16 \mu \mathrm{m}$

Considering the presence of various forms of ERs (with the serious potential of phytoestrogen sensitivity) in the pituitary gonadotropic and lactotropic cells, not only in the nucleus and cytoplasm but also in the membrane of rough endoplasmic reticulum and secretory vesicles, while keeping in mind that vesicular trafficking crucially defines cell mechanical status $(77,78)$, we can assume that the observed changes in cell morphology may be mediated by both genomic and non-genomic pathways. Short term exposure of immature female rats to genistein $(50 \mathrm{mg} / \mathrm{kg} / \mathrm{b}$. w.) induced significant increases in the number of FSH cells (by 21\%) and LH cells (by 20\%; 79). The study showed the increased volumes of FSH and LH cells by $19 \%$ and $20 \%$ and their volume densities by $20 \%$ and $20 \%$, so in this experimental model genistein acted as an estrogen agonist (Fig. 7; Fig. 8 and Fig. 9).
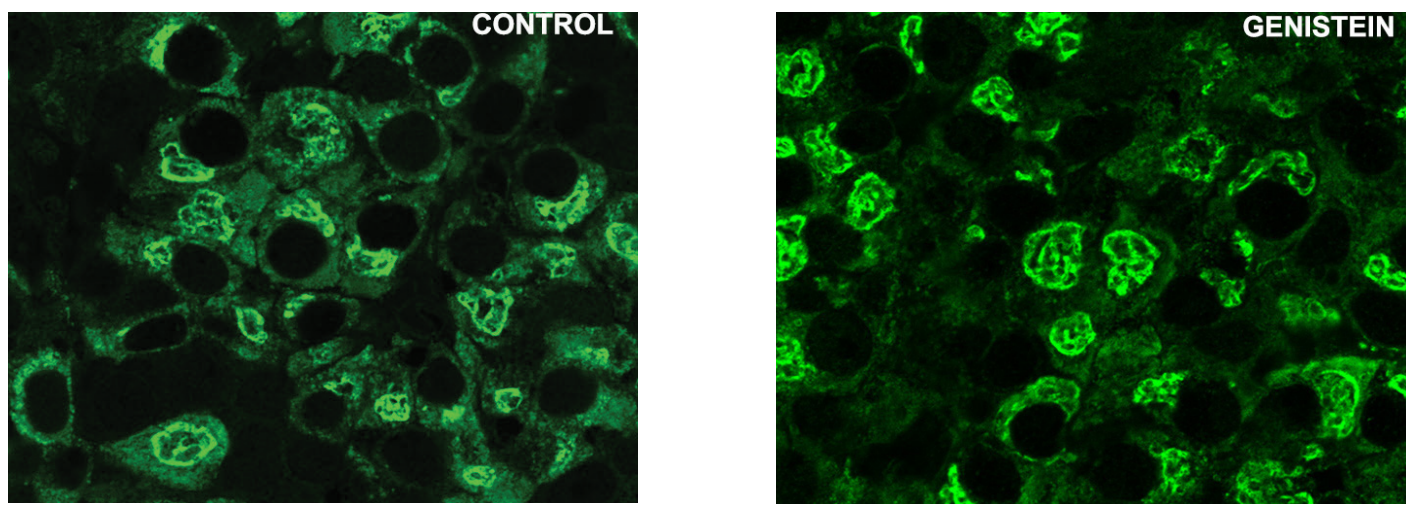

Figure 6. Immunoreactive lactotrops in the pituitary gland in control and genistein treated middle aged female rats. Scale bar $50 \mu \mathrm{m}$
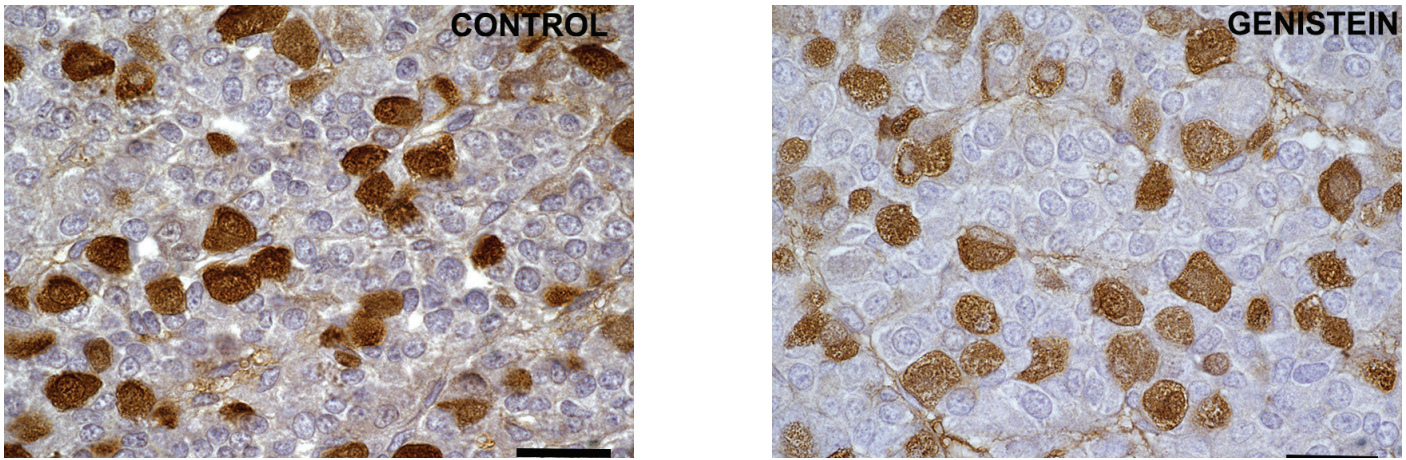

Figure 7. Immunoreactive follicle-stimulating hormone producing cells in the pituitary gland in control and genistein treated immature female rats. Scale bar $20 \mu \mathrm{m}$ 

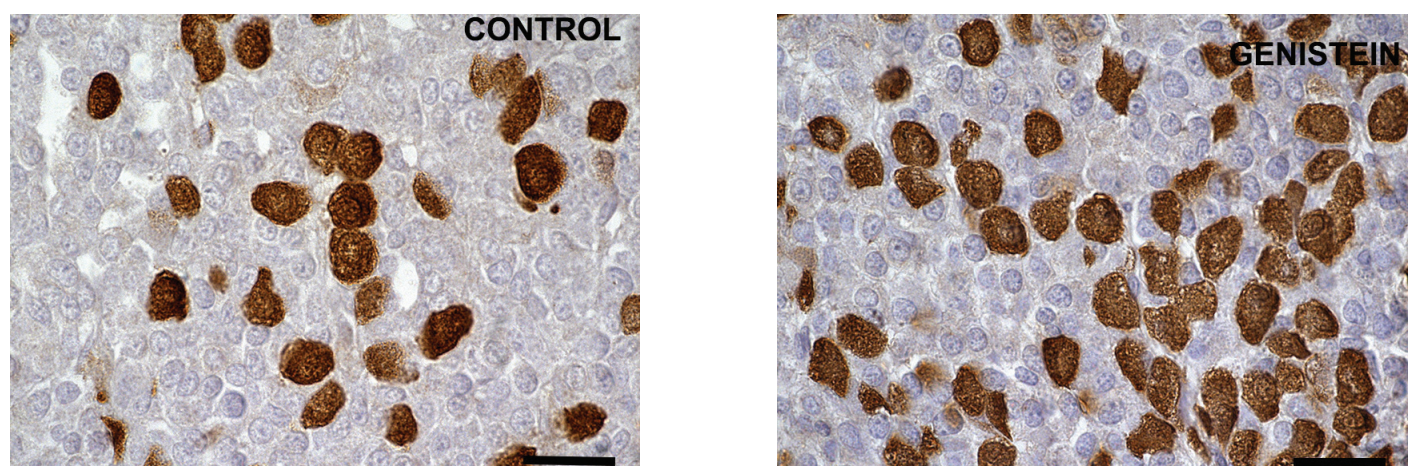

Figure 8. Immunoreactive luteinizing hormone producing cells in the pituitary gland in control and genistein treated immature female rats. Scale bar $20 \mu \mathrm{m}$
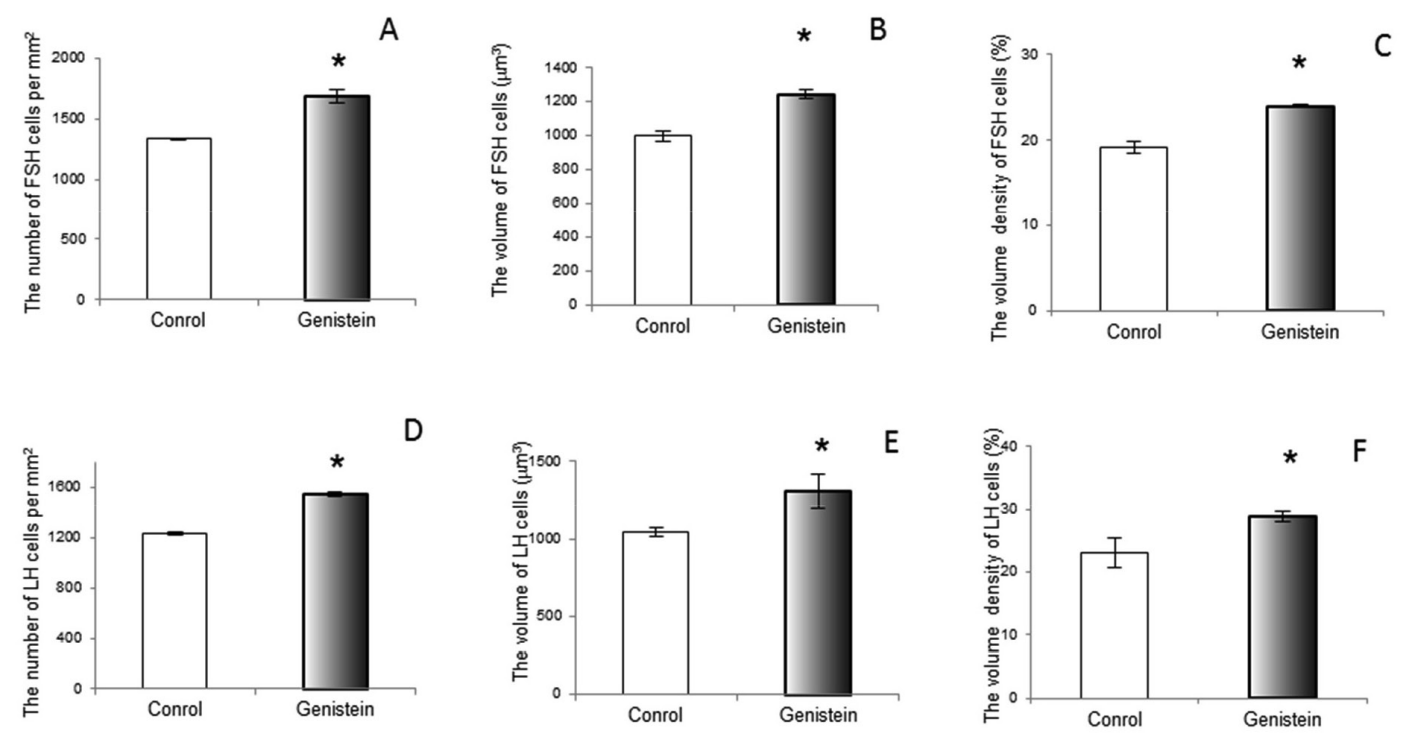

Figure 9. The number of follicle-stimulating hormone producing (FSH; A) and luteinizing hormone producing (LH; D) cell per $\mathrm{mm}^{2}$ (A); The volume of FSH (B) and LH (E) cell; The volume density of FSH (C) and LH (F) cell in control and genistein treated immature female rats. The values are means \pm standard deviation, $\mathrm{n}=6$ animals per group; $* \mathrm{p}<0.05$ vs. control

The serum concentration of FSH remained unchanged, while LH concentration increased after long-term administration of $\mathrm{G}$ to immature male rats (80). The previous study confirmed the enhanced LH $\beta$ mRNA expression and a greater proportion of LH cells after intracerebroventricular administration of $\mathrm{G}$ in ewes (81). However, in intact anestrus ewes LH cell percentage fell, but the associated increase of LH $\beta$ mRNA was presumed to be due to the stimulated rapid release of the hormone, following $G$ exposure (82). In aromatase knockout mice, oral or subcutaneous, genistein exposure reduced serum FSH and $\mathrm{LH}$ concentrations i.e., back to the levels found in wild type mice (83). When it comes to ACTH cells of adult rats, the chronic $\mathrm{G}$ treatment caused an increase in the total number of ACTH cells (67). The plurihormonal cells concept is probably responsible for the increased ACTH cell number. Namely, plurihormonal cells which contain both ACTH and gonadotropic hormones were detected within the population of rat pituitary corticotrophs (84). The unchanged volume of particular ACTH cells after chronic genistein application, together with reduced immunostaining intensity and elevated circulating ACTH level, most probably represent the consequence of the continuous synthetic and secretory activity of these cells, due to constant hypothalamic stimulation (Fig. 10 and Fig. 11). 

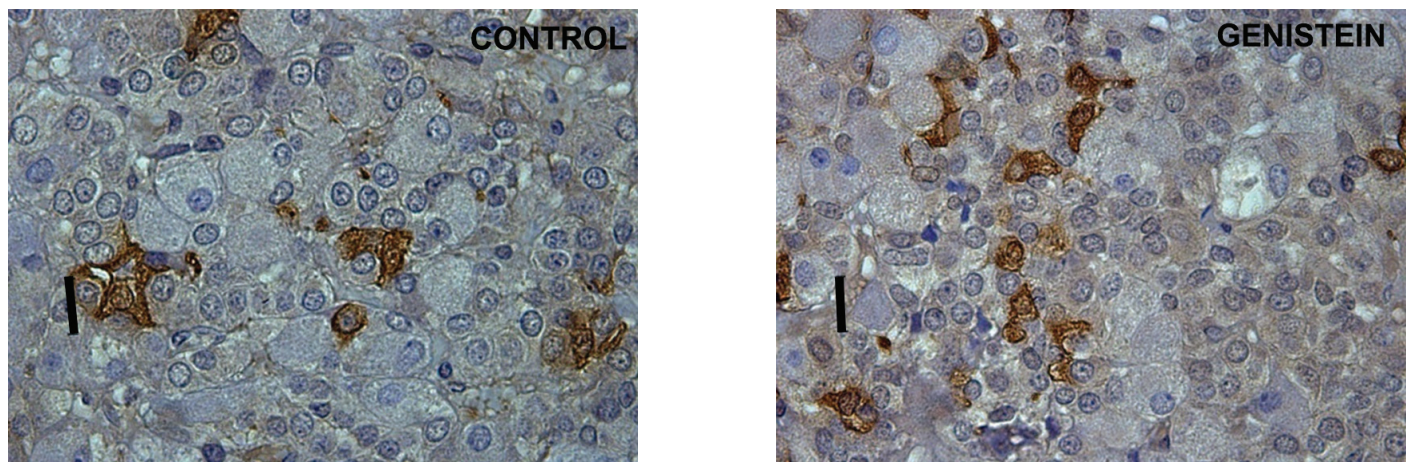

Figure 10. Immunoreactive corticotropes in the pituitary gland in control (C) and genistein treated (G) adult male rats. Scale bar $16 \mu \mathrm{m}$
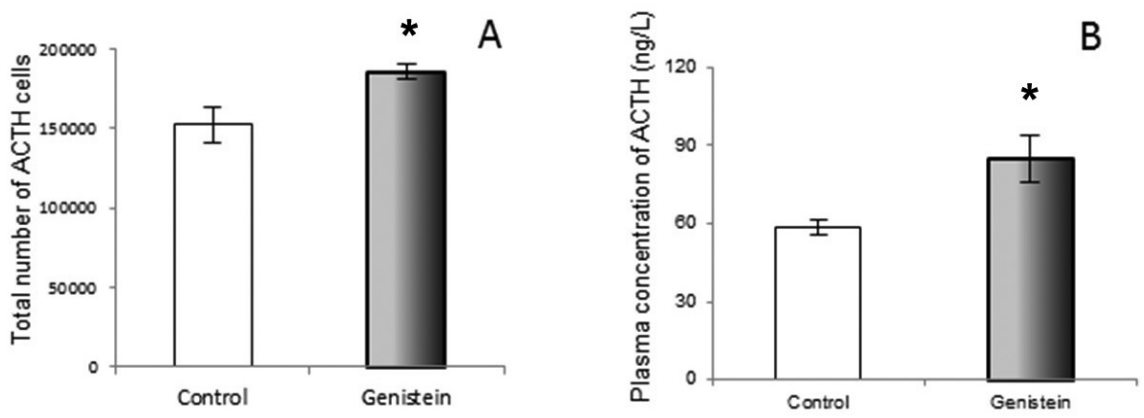

Figure 11. The total number of corticotropes (ACTH cells; A) and plasma concentration of ACTH (B) in control and genistein treated adult male rats. The values are means \pm standard deviation, $n=6$ animals per group; $* p<0.05$ vs. control

In contrast with the cited results, our work in middle-aged rats has shown the suppressive effects of genistein exposure on morphological parameters of ACTH cells, together with a lowering of blood ACTH levels (85; Fig. 12 and Fig. 13). Also, in vitro studies have shown the inhibitory action of genistein on rat pituitary cell proliferation (86). A likely explanation is the age-dependent decline in pituitary responsiveness to $\mathrm{CRH}$, i.e. in middleaged rats pituitary responsiveness is about $60 \%$ of that observed in young populations (87).
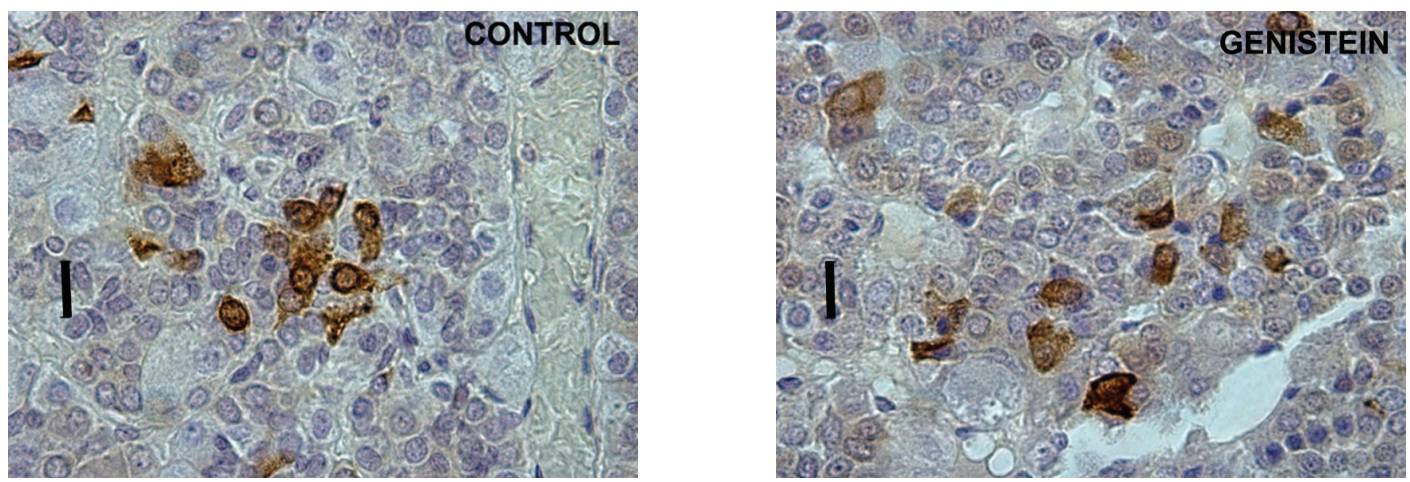

Figure 12. Immunoreactive corticotropes in the pituitary gland in control and genistein treated middle-aged rats. Scale bar $16 \mu \mathrm{m}$ 

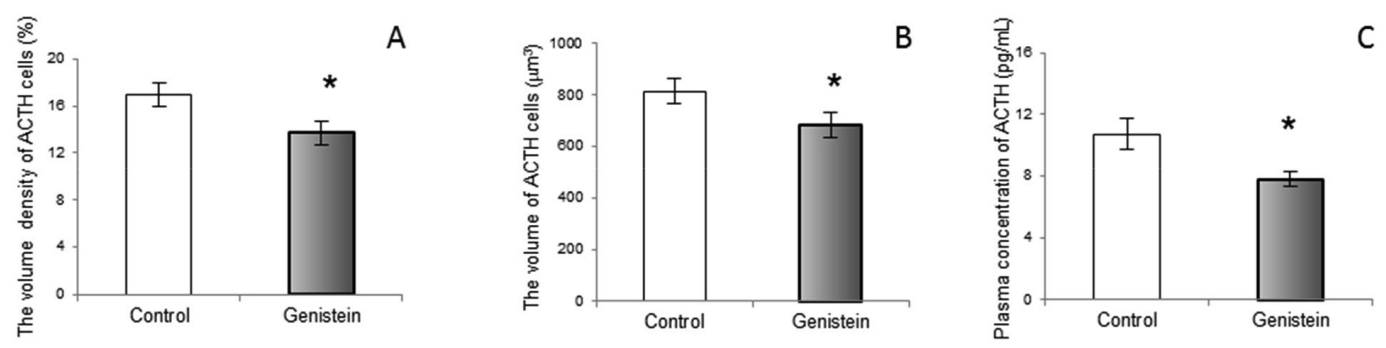

Figure 13. The volume density of corticotropes (ACTH cells; A), The volume of ACTH cells (B), plasma concentration of ACTH $(\mathrm{C})$ in control and genistein treated middle-aged male rats. The values are means \pm standard deviation, $\mathrm{n}=6$ animals per group; $* \mathrm{p}<0.05$ vs. control

Following genistein treatment pituitary TSH cells were larger and more numerous in middleaged rats. Also, their relative cellular volumes, as well as the relative volume density per pituitary, unit volume and serum TSH level significantly increased (Fig. 14 and Fig. 15). These changes are probably due to the release from the negative feedback effect of thyroid hormones. (88). Also, Modaresi et al. (89) obtained increased TSH level in mice feeding on soybean.
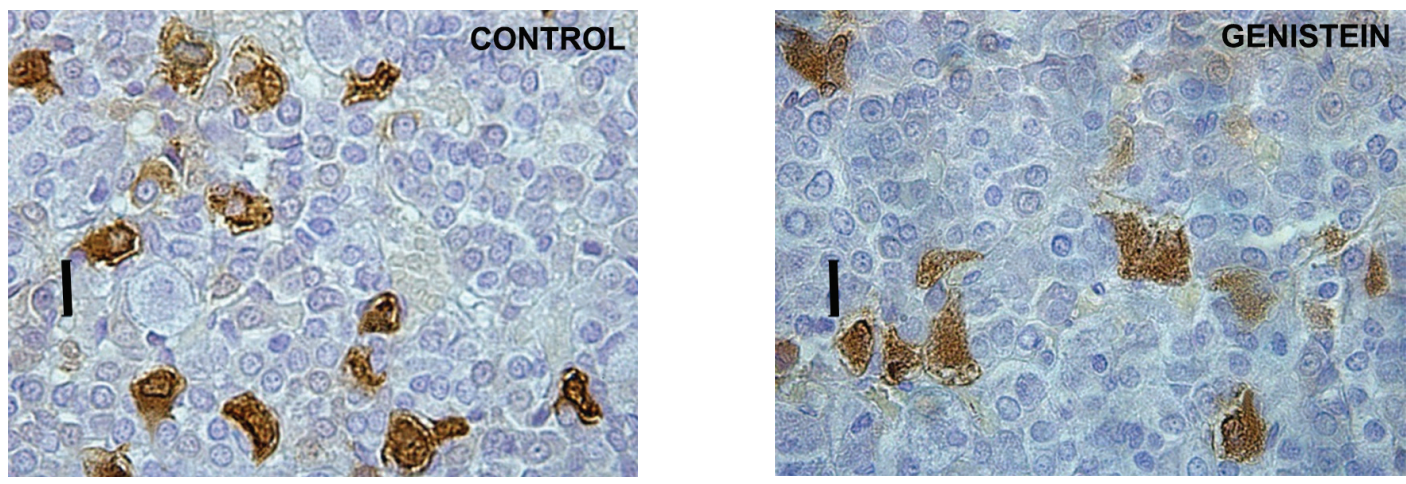

Figure 14. Immunoreactive thyrotrophs in the pituitary gland in control and genistein treated middle-aged male rats. Scale bar $16 \mu \mathrm{m}$
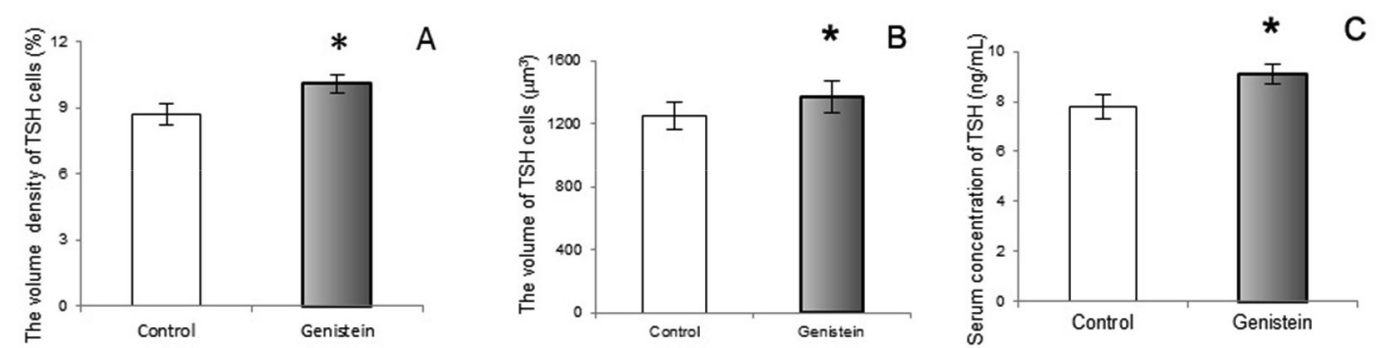

Figure 15. The volume density of thyrotrophs (TSH cells;A), The volume of TSH cells (B), Serum concentration of TSH (C) in control and genistein treated middle-aged male rats. The values are means \pm standard deviation, $\mathrm{n}=6$ animals per group; $* \mathrm{p}<0.05$ vs. control 


\section{CONCLUSION}

As with many other compounds, there are many benefits and weaknesses associated with genistein exposure. Unequivocally, genistein contributes to regulation of either morphological and/or functional features of all pituitary hormone producing cells. In which direction HP cells will undergo processes of remodeling following genistein exposure depends on gender, age, hormonal status and dose. Consumers should be aware that genistein is an endocrine disrupting compound and should make dietary choices accordingly.

\section{CONFLICT OF INTEREST STATEMENT}

The authors declared that they have no potential conflict of interest with respect to the authorship and/or publication of this article.

\section{ACKNOWLEDGEMENT}

This research was supported by grants from the Ministry of Education and Science of the Republic of Serbia (No.173009)

\section{REFERENCES}

1. Patisaul, H.B., Jefferson, W. (2010). The pros and cons of phytoestrogens. Front Neuroendocrinol. 31, 400-419. https://doi.org/10.1016/j.yfrne.2010.03.003 PMid:20347861 PMCid:PMC3074428

2. Setchell, K.D., Borriello, S.P., Hulme, P., Kirk, D.N., Axelson, M. (1984). Nonsteroidal estrogens of dietary origin: possible roles in hormone-dependent disease. Am J Clin Nutr. 40, 569-578. PMid:6383008

3. Wet, L., Birac, P.M., Pratt, D.E. (1978). Separation of the isomeric isoflavones from soybeans by highperformance liquid chromatography. J Chromatogr. 150, 266-268.

https://doi.org/10.1016/S0021-9673(01)92130-2

4. Cheng, E., Story, C.D., Yoder, L., Hale, W.H., Burrough, W. (1953). Estrogenic activity of isoflavone derivatives extracted and prepared from soybean oil meal. Science 118, 164-165.

https://doi.org/10.1126/science.118.3058.164 PMid:13076231

5. Batterham, T.J., Hart, N.K., Lamberton, J.A. (1965). Metabolism of oestrogenic isoflavones in sheep. Nature 4983, 509.

https://doi.org/10.1038/206509a0
6. Kuiper, G.G., Lemmen, J.G., Carlsson, B., Corton, J.C., Safe, S.H., van der Saag, P.T., van der Burg, B., Gustafsson, J.A. (1998). Interaction of estrogenic chemicals and phytoestrogens with estrogen receptor beta. Endocrinology 139, 4252-4263.

https://doi.org/10.1210/endo.139.10.6216

PMid:9751507

7. Lephart, E.D., West, T.W., Weber, K.S., Rhees, R.W., Setchell, K.D., Adlercreutz, H., Lund, T.D. (2002). Neurobehavioral effects of dietary soy phytoestrogens. Neurotoxicol Teratol. 24, 5-16. https://doi.org/10.1016/S0892-0362(01)00197-0

8. Kostelac, D., Rechkemmer, G., Briviba, K. (2003). Phytoestrogens modulate binding response of estrogen receptors alpha and beta to the estrogen response element. J Agric Food Chem. 51, 7632-7635. https://doi.org/10.1021/jf034427b PMid:14664520

9. Patisaul, H.B. (2005). Phytoestrogen action in the adult and developing brain. J Neuroendocrinol. 17, 57-64.

https://doi.org/10.1111/j.1365-2826.2005.01268.x PMid:15720476

10. Setchell, K.D., Cassidy, A. (1999). Dietary isoflavones: biological effects and relevance to human health. J Nutr. 129, 758-767.

11. Adlercreutz, H., Mazur, W. (1997). Phyto-oestrogens and Western diseases. Ann Med. 29, 95-120. https://doi.org/10.3109/07853899709113696 PMid:9187225

12. Shemesh, M., Lindner, H. R., Ayalaoan, N. (1972). Affinity of rabbit uterine oestradiol receptor for phyto-oestrogens and its use in a competitive protein-binding radioassay for plasma coumestrol. J Reprod Fertil. 29, 1-9.

https://doi.org/10.1530/jrf.0.0290001

PMid:5017011

13. Piontek, M., Hangels, K.J., Porschen, R., Strohmeyer, G. (1993). Anti-proliferative effect of tyrosine kinase inhibitors in epidermal growth factor stimulated growth of human gastric cancer cells. Anticancer Res. 13, 2119-2123.

PMid:8297123

14. Boutin, J.A. (1994). Tyrosine protein kinase inhibition and cancer. Int J Biochem Cell Bio. 26, 1203-1226.

https://doi.org/10.1016/0020-711X(94)90091-4

15. Kurzer, M.S., Xia, X. (1997). Dietary Phytoestrogens Annu Rev Nutr. 17, 353-381.

https://doi.org/10.1146/annurev.nutr.17.1.353

PMid:9240932 
16. Okura, A., Arakawa, H., Oka, H., Yoshinari, T., Monden, Y. (1988). Effect of genistein on topoisomerase activity and on the growth of [Val 12] Ha-ras-transformed NIH 3T3 cells. Biochem Biophys Res Commun. 157, 183-189. https://doi.org/10.1016/S0006-291X(88)80030-5

17. Hu, G.,X, Zhao, B.H., Chu, Y.H., Zhou, H.Y., Akingbemi, B.T., Zheng, Z.Q, Ge, R.S. (2010). Effects of genistein and equol on human and rat testicular 3beta-hydroxysteroid dehydrogenase and 17beta-hydroxysteroid dehydrogenase 3 activities. Asian J Androl. 12(4): 519-526.

https://doi.org/10.1038/aja.2010.18

PMid:20453869 PMCid:PMC3739362

18. Adlercreutz, H. (1990). Western diet and Western diseases: some hormonal and biochemical mechanisms and associations. Scand J Clin Lab Invest Suppl. 201, 3-23.

https://doi.org/10.1080/00365519009085798

PMid:2173856

19. Wang, H., Li, J., Gao, Y., Xu, Y., Pan, Y., Tsuji, I., Sun, Z.J., Li, X.M. (2010). Xeno-oestrogens and phyto-oestrogens are alternative ligands for the androgen receptor. Asian J Androl. 12, 535-547.

https://doi.org/10.1038/aja.2010.14

PMid:20436506 PMCid:PMC3739360

20. Lee, H.P., Gourley, L., Duffy, S.W., Estève, J., Lee, J., Day, N.E. (1991). Dietary effects on breast-cancer risk in Singapore. Lancet 337, 1197-1200. https://doi.org/10.1016/0140-6736(91)92867-2

21. Adlercreutz, H., Honjo, H., Higashi, A., Fotsis, T., Hämäläinen, E., Hasegawa, T., Okada, H. (1991). Urinary excretion of lignans and isoflavonoid phytoestrogens in Japanese men and women consuming a traditional Japanese diet. Am J Clin Nutr. 54, 1093-1100.

PMid:1659780

22. Ingram, D., Sanders, K., Kolybaba, M., Lopez, D. (1997). Case-control study of phyto-oestrogens and breast cancer. Lancet 350, 990-994. https://doi.org/10.1016/S0140-6736(97)01339-1

23. Shimizu, H., Ross, R.K., Bernstein, L., Yatani, R., Henderson, B.E., Mack, T.M. (1991). Cancers of the prostate and breast among Japanese and white immigrants in Los Angeles County. Br J Cancer. 63, 963-966.

https://doi.org/10.1038/bjc.1991.210

PMid:2069852 PMCid:PMC1972548

24. Watanabe, S., Koessel, S (1993). Colon cancer: an approach from molecular epidemiology. J Epidemiol. 3, 47-61. https://doi.org/10.2188/jea.3.47
25. Severson, R.K., Nomura, A.M., Grove, J.S., Stemmermann, G.N. (1989). A prospective study of demographics, diet, and prostate cancer among men of Japanese ancestry in Hawaii. Cancer Res. 49, 1857-1860.

PMid:2924323

26. Anthony, M.S., Clarkson, T.B., Hughes, C.L.Jr., Morgan, T.M., Burke, G.L. (1996). Soybean isoflavones improve cardiovascular risk factors without affecting the reproductive system of peripubertal rhesus monkeys. J Nutr. 126, 43-50. PMid:8558324

27. Tikkanen, M.J., Wahala, K., Ojala, S., Vihma, V., Adlercreutz, H. (1998). Effect of soybean phytoestrogen intake on low density lipoprotein oxidation resistance. Proc Natl Acad Sci USA 95, 3106-3110.

https://doi.org/10.1073/pnas.95.6.3106

PMid:9501223 PMCid:PMC19702

28. Raines, E.W., Ross, R. (1995). Biology of atherosclerotic plaque formation: possible role of growth factors in lesion development and the potential impact of soy. J Nutr. 125, 624630 .

29. Šošić-Jurjević, B., Filipović, B., Ajdžanović, V., Brkić, D., Ristić, N., Stojanoski, M.M., Nestorović, N., Trifunović, S., Sekulić. M (2007). Subcutaneously administrated genistein and daidzein decrease serum cholesterol and increase triglyceride levels in male middle-aged rats. Exp Biol Med. 232, 1222-1227.

https://doi.org/10.3181/0703-BC-82

PMid:17895530

30. Filipović, B., Šošić-Jurjević, B., Ajdžanović, V., Brkić, D., Manojlović-Stojanoski, M., Milošević, V., Sekulić, M. (2010). Daidzein administration positively affects thyroid $\mathrm{C}$ cells and bone structure in orchidectomized middle-aged rats. Osteoporos Int. 21, 1609-1616.

https://doi.org/10.1007/s00198-009-1092-x PMid:19859640

31. Messina, M., Ho, S., Alekel, D.L. (2004) Skeletal benefits of soy isoflavones: a review of the clinical trial and epidemiologic data. Curr Opin Clin Nutr Metab Care. 7(6): 649-658. https://doi.org/10.1097/00075197-200411000-00010

32. Dalais, F.S., Rice, G.E., Wahlqvist, M.L., Grehan, M., Murkies, A.L., Medley, G., Ayton, R., Strauss, B.J. (1998). Effects of dietary phytoestrogens in postmenopausal women. Climacteric 1, 124-129. https://doi.org/10.3109/13697139809085527 PMid:11907915 
33. Miao Q., Li J., Miao S., Hu N., Zhang J., Zhang S., Xie Y., Wang J., Wang S. (2012). The bone-protective effect of genistein in the animal model of bilateral ovariectomy: Roles of phytoestrogens and PTH/ PTHR1 against post-menopausal osteoporosis. Int J Mol Sci. 13(1): 56-70.

PMid:22312238

34. Adlercreutz, C.H., Goldin, B.R., Gorbach, S.L., Hockerstedt, K.A., Watanabe, S., Hamalainen, E.K., Markkanen, M.H., Makela, T.H., Wahala, K.T., Adlercreutz, T. (1995). Soybean phytoestrogen intake and cancer risk. J Nutr. 125, 757-770.

35. Ajdžanović, V., Šosić-Jurjević, B., Filipović, B., Trifunović, S., Manojlović-Stojanoski, M., Sekulić, M., Milosević, V. (2009). Genistein-induced histomorphometric and hormone secreting changes in the adrenal cortex in middle-aged rats. Exp Biol Med (Maywood). 234, 148-156.

https://doi.org/10.3181/0807-RM-231

PMid:19064942

36. Banerje, S., Li, Y., Wang, Z., Sarkar, F.H. (2008) Multi-target therapy of cancer by genistein Cancer Lett. 269(2): 226-242.

https://doi.org/10.1016/j.canlet.2008.03.052

PMid:18492603 PMCid:PMC2575691

37. Jefferson, W.N., Couse, J.F., Padilla-Banks, E., Korach, K.S., Newbold, R.R. (2002). Neonatal exposure to genistein induces estrogen receptor (ER) alpha expression and multioocyte follicles in the maturing mouse ovary: evidence for ER betamediated and nonestrogenic actions. Biol Reprod. 67, 1285-1296.

https://doi.org/10.1095/biolreprod67.4.1285

PMid:12297547

38. Jefferson,W.N., Padilla-Banks, E., Newbold, R.R. (2007). Disruption of the developing female reproductive system by phytoestrogens: genistein as an example. Mol Nutr Food Res. 51, 832-844.

https://doi.org/10.1002/mnfr.200600258

PMid:17604387

39. Medigović, I.M., Živanović, J.B., Ajdžanović, V.Z., Nikolić-Kokić, A.L., Stanković, S.D., Trifunović, S.L., Milošević, V.Lj., Nestorović, N.M. (2015). Effects of soy phytoestrogens on pituitary-ovarian function in middle-aged female rats. Endocrine 50, 764-776.

https://doi.org/10.1007/s12020-015-0691-x PMid:26215277

40. Lindner, H.R. (1976). Occurrence of anabolic agents in plants and their importance. Environ Qual Safety Suppl. pp. 151-158.
41. Allred, C.D., Allred, K.F., Ju, Y.H., Virant, S.M., Helferich, W.G. (2001). Soy diets containing varying amounts of genistein stimulate growth of estrogendependent (MCF-7) tumors in a dose-dependent manner. Cancer Res. 61, 5045-5050.

PMid:11431339

42. Ju, Y.H., Allred, C.D., Allred, K.F., Karko, K.L., Doerge, D.R., Helferich, W.G. (2001). Physiological concentrations of dietary genistein dose-dependently stimulate growth of estrogen-dependent hum and breast cancer (MCF-7) tumors implanted in athymic nude mice. J Nutr. 131, 2957-2962.

PMid:11694625

43. Unfer, V., Casini, M.L., Costabile, L., Mignosa, M., Gerli, S., Di Renzo, G.C. (2004). Endometrial effects of long-term treatment with phytoestrogens: a randomized, double-blind, placebo-controlled study. Fertil Steril. 82, 145-148.

https://doi.org/10.1016/j.fertnstert.2003.11.041 PMid:15237003

44. Nohynek, G.J., Borgert, C.J., Dietrich, D., Rozman, K.K. (2013). Endocrine disruption: fact or urban legend? Toxicol Lett. 223, 295-305. https://doi.org/10.1016/j.toxlet.2013.10.022 PMid:24177261

45. Goldin, B.R., Brauner, E., Adlercreutz, H., Ausman, L.M., Lichtenstein, A.H. (2005). Hormonal response to diets high in soy or animal protein without and with isoflavones in moderately hypercholesterolemic subjects. Nutr Cancer. 51, 1-6. https://doi.org/10.1207/s15327914nc5101_1 PMid:15749623

46. Jabbar, M.A., Larrea, J., Shaw, R.A. (1997). Abnormal thyroid function tests in infants with congenital hypothyroidism: the influence of soybased formula. J Am Coll Nutr. 16, 280-282. https://doi.org/10.1080/07315724.1997.10718686 PMid:9176836

47. Divi, R.L., Chang, H.C., Doerge, D.R. (1997). Anti-thyroid isoflavones from soybean: isolation, characterization, and mechanisms of action. Biochem Pharmacol. 54, 1087-1096. https://doi.org/10.1016/S0006-2952(97)00301-8

48. Persky, V.W., Turyk, M.E., Wang, L., Freels, S., Chatterton, R.Jr., Barnes, S., Erdman, J.Jr., Sepkovic, D.W., Bradlow, H.L., Potter, S. (2002). Effect of soy protein on endogenous hormones in postmenopausal women. Am J Clin Nutr. 75, 145153.

PMid:11756072 
49. Patisaul H., Jefferson W. (2010). The pros and cons of phytoestrogens Front Neuroendocrinol. 31(4): 400-419.

https://doi.org/10.1016/j.yfrne.2010.03.003

PMid:20347861 PMCid:PMC3074428

50. Cone R., Low M., Elmquist J., Cameron J. D. (2011). Anterior pituitary. In: Larsen PR, Kronenberg HM., Melmed S., Plonsky KS, (Eds.), Williams: Text book of Endocrinology. (pp. 81-176). Philadelphia: WB Saunders Company.

PMCid:PMC1308188

51. Melmed, S., Kleinberg. (2011). Anterior pituitary. In: Larsen PR, Kronenberg HM., Melmed S., Plonsky KS, (Eds.), Williams: Text book of Endocrinology. (pp. 175-279). Philadelphia: WB Saunders Company.

52. Muller, E.E., Locatelli, V., Cocchi, D. (1999) Neuroendocrine control of growth hormone secretion. Physiol Rev. 79, 511-607.

PMid:10221989

53. Whitnall, M.H. (1993). Regulation of the hypothalamic corticotropin-releasing hormone neurosecretory system. Progr Neurobiol. 40, 573-629.

https://doi.org/10.1016/0301-0082(93)90035-Q

54. Brooks, A. N. (1998). Natural and anthropogenic environmental oestrogens: the scientific basis for risk assessment. Comparative physiology of the reproductive endocrine system in laboratory rodents and humans. Pure Appl Chem. 70, 1633-1646.

https://doi.org/10.1351/pac199870091633

55. Horvath, E., Kovacs, K. (1988). Fine structural cytology of the adenohypophysis in rat and man. $\mathrm{J}$ Electron Microsc Tech. 8, 401-432.

https://doi.org/10.1002/jemt.1060080410 PMid:3058887

56. Dada, M.O., Campbell, G.T., Blake, C.A. (1984). Pars distalis cell quantification in normal adult male and female rats. J Endocrinol. 101, 87-94 https://doi.org/10.1677/joe.0.1010087

57. Milošević, V., Brkić, B., Velkovski, S.D., Sekulić, M., Lovren, M., Starčević, V., Severs W.B. (1998). Morphometric and functional changes of rat pituitary somatotropes and lactotropes after central administration of somatostatin. Pharmacology 57 , 28-34.

https://doi.org/10.1159/000028223

PMid:9670210

58. Milošević, V., Ajdžanović, V. (2014). Pituitary hormone-producing cells after estradiol application in rat models of menopause. Serbian Journal of Experimental and Clinical Research 15, 115-120. https://doi.org/10.5937/sjecr1403115M
59. Milosević, V., Sekulić, M., Brkić, B., Lovren, M., Starcević, V. (2000). Effect of centrally administered somatostatin on pituitary thyrotropes in male rats. Histochem J. 32, 565-569.

https://doi.org/10.1023/A:1004158412915

PMid:11127978

60. Vankelecom, H. (2007). Non-hormonal cell types in the pituitary candidating for stem cell. Semin Cell Dev Biol. 18, 559-570.

https://doi.org/10.1016/j.semcdb.2007.04.006

PMid:17509912

61. Vankelecom, H., Gremeaux, L. (2010). Stem cells in the pituitary gland: A burgeoning field. Gen Comp Endocrinol. 166, 478-488.

https://doi.org/10.1016/j.ygcen.2009.11.007

PMid:19917287

62. Hauspie, A., Seuntjens, E.,Vankelecom, H., Denef, C. (2003). Stimulation of combinatorial expression of prolactin and glycoprotein hormone alpha-subunit genes by gonadotropin-releasing hormone and estradiol-17beta in single rat pituitary cells during aggregate cell culture. Endocrinology 144, 388-399. https://doi.org/10.1210/en.2002-220606

PMid:12488367

63. Mignot, M., Skinner, D.C. (2005). Colocalization of $\mathrm{GH}, \mathrm{TSH}$ and prolactin, but not ACTH, with beta LH-immunoreactivity: evidence for pluripotential cells in the ovine pituitary. Cell Tissue Res. 319, 413-421.

https://doi.org/10.1007/s00441-004-1009-0

PMid:15647919

64. Mitchner, N.A., Garlick, C., Ben-Jonathan, N. (1998). Cellular distribution and gene regulation of estrogen receptors alpha and beta in the rat pituitary gland. Endocrinology 139, 3976-3983.

https://doi.org/10.1210/endo.139.9.6181

PMid:9724053

65. Yin, P., Kawashima, K., Arita, J. (2002). Direct actions of estradiol on the anterior pituitary gland are required for hypothalamus-dependent lactotrope proliferation and secretory surges of luteinizing hormone but not of prolactin in female rats. Neuroendocrinology 75, 392-401.

https://doi.org/10.1159/000059436

PMid:12065892

66. Milošević, V., Starčević V., Šošić-Jurjević, B., Filipović, B., Trifunović, S., Ristić, N., Nestorović, N., Manojlović, M., Sekulić, M. (2007). Effect of estradiol or calcium treatment on mammotrophs of female middle-aged rats. Acta Vet. 57, 393-402. https://doi.org/10.2298/AVB0706393M 
67. Trifunović, S., Manojlović-Stojanoski, M., Ajdzanović, V., Nestorović, N., Ristić, N., Medigović, I., Milošević V. (2012). Genistein stimulates the hypothalamopituitary-adrenal axis in adult rats: morphological and hormonal study. Histol Histopathol. 27, 627-640. PMid:22419027

68. Trifunović, S., Manojlović-Stojanoski,M.,Ajdžanović, V., Nestorović, N., Ristić, N., Medigović, I., Milošević, V. (2014). Effects of genistein on stereological and hormonal characteristics of the pituitary somatotrophs in rats. Endocrine 47, 869-877.

https://doi.org/10.1007/s12020-014-0265-3

PMid:24752394

69. Sekulić, M., Lovren, M., Milosević, V. (1998). Immunoreactive TSH cells in the pituitary of female middle-aged rats after treatment with estradiol or calcium. Acta Histochem. 100, 185-191 https://doi.org/10.1016/S0065-1281(98)80026-3

70. von Bartheld CS1, Wouters FS, Quantitative techniques for imaging cells and tissues. Cell Tissue Res. 2015 Apr;360(1): 1-4.

https://doi.org/10.1007/s00441-015-2149-0

PMid:25773453 PMCid:PMC4380763

71. Childs, G.V. (2002). Development of gonadotropes may involve cyclic transdifferentiation of growth hormone cells. Arch Physiol Biochem. 110, 42-49. https://doi.org/10.1076/apab.110.1.42.906 PMid:11935399

72. Trifunović S., Manojlović-Stojanoski M., Ristić N., Nestorović N., Medigović I., Živanović J., Milošević V. (2016). Changes of growth hormone-releasing hormone and somatostatin neurons in the rat hypothalamus induced by genistein: a stereological study. Nutr Neurosci. 19(10): 467-474.

https://doi.org/10.1179/1476830514Y.0000000143

73. Shimizu, T., Kamegai, J., Tamura, H., Ishii, S., Sugihara, H., Oikawa, S. (2005). The estrogen receptor (ER) alpha, but not ER beta, gene is expressed in hypothalamic growth hormonereleasing hormone neurons of the adult female rat. Neurosci Res. 52, 121-125.

https://doi.org/10.1016/j.neures.2005.02.002 PMid:15811559

74. Misztal, T., Wańkowska, M., Górski, K., Romanowicz, K. (2007). Central estrogen-like effect of genistein on growth hormone secretion in the ewe. Acta Neurobiol Exp (Wars). 67, 411-419.

75. Ajdžanović, V., Medigović, I., Živanović, J., ŠošićJurjević B., Trifunović, S., Tanić, N., Miločević,V. (2014). Immunohistomorphometric and fluorescent characteristics of $\mathrm{GH}$ cells after treatment with genistein or daidzein in an animal model of andropause. Acta Vet. 64, 93-104.

https://doi.org/10.2478/acve-2014-0010
76. Romanowicz, K., Misztal, T., Barcikowski, B. (2004). Genistein, a phytoestrogen, effectively modulates luteinizing hormone and prolactin secretion in ovariectomized ewes during seasonal anestrus. Neuroendocrinology 79, 73-81.

https://doi.org/10.1159/000076630

PMid:15004429

77. Gonzalez, M., Reyes, R., Damas, C., Alonso, R., Bello, AR. (2008). Estrogen receptor alpha and beta in female rat pituitary cells, an immunochemical study. Gen Comp Endocrinol. 155, 857-868. https://doi.org/10.1016/j.ygcen.2007.10.007 PMid:18067893

78. Asnacios, A., Hamant, O. (2012). The mechanics behind cell polarity. Trends Cell Biol. 22, 584-591. https://doi.org/10.1016/j.tcb.2012.08.005 PMid:22980034

79. Medigović, I., Ristić, N., Trifunović, S., ManojlovićStojanoski, M., Milošević, V., Zikić, D., Nestorović, N. (2012). Genistein affects ovarian folliculogenesis: a stereological study. Microsc Res Tech. 75, 16911699.

https://doi.org/10.1002/jemt.22117

PMid:22927040

80. Ohno, S., Nakajima, Y., Inoue, K., Nakazawa, H., Nakajin, S. (2003). Genistein administration decreases serum corticosterone and testosteronelevels in rats. Life Sci. 74, 733-742.

https://doi.org/10.1016/j.lfs.2003.04.006 PMid:14654166

81. Wójcik-Gładysz, A., Romanowicz, K., Misztal, T., Polkowska, J., Barcikowski,B. (2005). Effects of intracerebroventricular infusion ofgenistein on the secretory activity of the GnRH/LH axis in ovariectomized ewes. Anim Reprod Sci. 86, 221235.

https://doi.org/10.1016/j.anireprosci.2004.08.004 PMid:15766802

82. Polkowska, J., Ridderstråle, Y., Wankowska, M., Romanowicz, K., Misztal, T., Madej, A. (2004). Effects of intracerebroventricular infusion of genistein on gonadotrophin subunit mRNA and immunoreactivity of gonadotrophins and oestrogen receptor-alpha in the pituitary cells of the anoestrous ewe. J Chem Neuroanat. 28, 217-224.

https://doi.org/10.1016/j.jchemneu.2004.07.004 PMid:15531133

83. Bliedtner, A., Zierau, O., Albrecht, S., Liebhaber, S., Vollmer, G. (2010). Effects of genistein and estrogen receptor subtype-specific agonists in ArKO mice following different administration routes. Mol Cell Endocrinol. 314, 41-52.

https://doi.org/10.1016/j.mce.2009.07.032 PMid:19686804 
84. Childs, G.V., Ellison, D.G., Ramaley, J.A. (1982). Storage of anteriorlobe adrenocorticotropin in corticotropes and a subpopulation of gonadotropes during the stress-nonresponsive period in the neonatal male rat. Endocrinology 110, 1676-1692.

https://doi.org/10.1210/endo-110-5-1676

PMid:6280971

85. Milošević, V., Ajdžanović, V., Sošic-Jurjevic, B., Filipovic, B., Brkic, M., Nestorovic, N., Sekulic, M. (2009). Morphofunctional characteristics of ACTH cells in middle-aged male rats after treatment with genistein. Gen Physiol Biophys 28, 94-97. https://doi.org/10.4149/gpb_2009_01_94 PMid:19390142

86. Zhang, Q.H., Hu, Y.Z., Zhou, S.S., Wang F.Z. (2001). Inhibitory effect,of,genistein on the proliferation of the anterior pituitary cells of rats. Sheng Li Xue Bao 53, 51-54.

PMid:11354798
87. Hauger, R.L., Thrivikraman, K.V. Plotsky, P.M. (1994). Age-related alterations of hypothalamicpituitary-adrenal axis function in male Fischer 344 rats. Endocrinology 134, 1528-1536.

https://doi.org/10.1210/endo.134.3.8119195

PMid:8119195

88. Šošić-Jurjević, B., Filipović, B., Ajdžanović, V., Savin, S., Nestorović, N., Milošević, V., Sekulić, M. (2010). Suppressive effects of genistein and daidzein on pituitary-thyroid axis in orchidectomized middle-aged rats. Exp Biol Med (Maywood). 235, 590-598.

https://doi.org/10.1258/ebm.2009.009279

PMid:20463299

89. Modaresi, M., Khorrami, H., Asadi-Samani, M. (2014). The effect of feeding with soybean on serum levels of TSH, T3 and T4 in male mice. J Herb Med Pharmacol. 3, 93-96. 